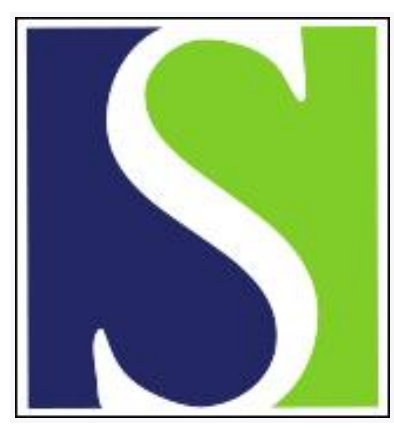

Scand J Work Environ Health 1976;2(1):50-53

https://doi.org/10.5271/sjweh.2832

Issue date: 1976

\title{
Gases formed from furan binding agents.
}

by Virtamo M, Tossavainen A

Key terms: formaldehyde; foundry; furan binding agent; furan resin binder; furfuryl alcohol; gas

This article in PubMed: www.ncbi.nlm.nih.gov/pubmed/968465

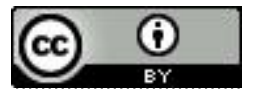




\title{
Gases formed from furan binding agents
}

\author{
by MATTI VIRTAMO, M.Sc., ${ }^{1}$ and ANTTI TOSSAVAINEN, Lic.Sc. (Eng.) ${ }^{2}$
}

\begin{abstract}
VIRTAMO, M. and TOSSAVAINEN, A. Gases formed from furan binding agents. Scand. $j$. work environ. \& health 2 (1976): suppl. 1, 50-53. Furfuryl alcohol and formaldehyde concentrations in the air of coremaking areas of 10 iron and steel foundries were measured. The mean concentration of furfuryl alcohol and formaldehyde was $4.3 \mathrm{~cm}^{3} / \mathrm{m}^{3}$ and $2.7 \mathrm{~cm}^{3} / \mathrm{m}^{3}$, respectively. Furfuryl alcohol exceeded its threshold limit value (TLV) of $5 \mathrm{~cm}^{3} / \mathrm{m}^{3}$ in $22 \%$ of the determinations; and formaldehyde $\left(\mathrm{TLV}=2 \mathrm{~cm}^{3} / \mathrm{m}^{3}\right.$ ) in $38 \%$. In addition phenol concentration was determined in one foundry; and phosphoric acid concentration, in two foundries. The concentrations of phenol and phosphoric acid were far lower than their TLVs. The question is raised as to whether exposure to furfuryl alcohol and formaldehyde in foundries in combination with exposure to dust and smoking can increase the risk of chronic bronchitis.
\end{abstract}

Key words: foundry, furan resin binders, furfuryl alcohol, formaldehyde.

Ever since 1960 cold-setting furan resins have been used in foundries as binding agents for sand, mainly in coremaking. Cores made with these resins have the following technical advantages: they harden fast, have accurate dimensions, and collapse easily after casting $(5,7,13)$.

Chemically, furan binders are copolymers of furfuryl alcohol (I) with either urea-formaldehyde (II) or phenol-formaldehyde (III) resins. Urea-furan resins are used in iron founding; and phenolfuran resins, in steel founding $(15,16)$.

1 Uusimaa Regional Institute of Occupational Health, Helsinki, Finland.

2 Department of Industrial Hygiene and Toxicology, Institute of Occupational Health, Helsinki, Finland.

Reprint requests to: Mr. Matti Virtamo, Uusimaa Regional Institute of Occupational Health, Arinatie 3, FIN-00370 Helsinki, Finland.

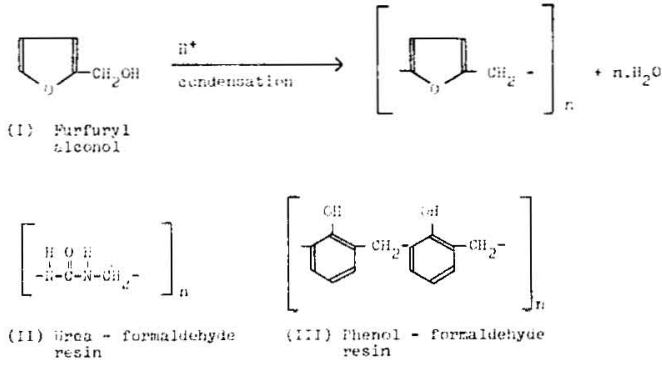

Prepolymers of furan resins are delivered to the foundries as liquids in which the furfuryl alcohol content varies from 50 to $95 \%$. They are polymerized into insoluble macromolecules by the action of the acid catalyst. Phosphoric acid or ptoluene sulphonic acid is used for the hardening of the resins.

Furan sand is prepared either in batches or in a continued mixing process. First about $1 \%$ of the hardener is added to the sand, and then resin, equaling about $2 \%$ of the weight of the sand, is added. The 
hardening of the core begins immediately, and adding more of the curing agent will speed up the process. The mixture is used at once and hardens in the core box in 1 to $2 \mathrm{~h}(5,13)$.

One disadvantage of furan resin is the irritating gases that are formed during coremaking. Unhardened resin includes free furfuryl alcohol, small amounts (1$3 \%$ ) of free formaldehyde, and possibly small amounts of free phenol; some part of all of these materials vaporizes into the workroom air during the sand mixing and the filling of the core boxes. An exothermic hardening reaction increases the evaporation.

The pyrolysis of furan resins during casting produces carbon monoxide and possibly small amounts of formaldehyde, phenol, and nitrogen oxide.

\section{MATERIALS AND METHODS}

Furan sand is used in 25 Finnish foundries in which a total of about 400 workers are exposed to furfuryl alcohol and formaldehyde. These workers include both coremakers and those present in the coremaking vicinity. A furan resin made up of $50 \%$ furfuryl alcohol and $50 \%$ ureaformaldehyde with a curing agent of phosphoric acid is used for iron casting, whereas one of $50 \%$ furfuryl alcohol and $50 \%$ phenol-formaldehyde with a curing agent of phosphoric acid is employed for steel casting.

Furfuryl alcohol and formaldehyde concentrations were measured in the coremaking areas of 10 iron and steel foundries. A total of 36 furfuryl alcohol and 43 formaldehyde samples were taken.

Phenol concentration was measured in one foundry (6 samples) and phosphoric acid concentration in two foundries (9 samples).

The air samples were collected as close to the breathing area of the workers as possible with liquid absorption.

Furfuryl alcohol measurements were made according to the method described by Pfäffli (14). The vapors were absorbed in water, and furfuryl alcohol was determined as a cyclic hydrazone compound with an ultraviolet spectrophotometer. The sampling time was $1-2 \mathrm{~h}$ and the lowest detectable concentration of furfuryl al- cohol in a 100-1 sample was $0.2 \mathrm{~cm}^{3} / \mathrm{m}^{3}$.

The formaldehyde concentrations were determined by the method of Goldman and Yagoda $(1,8)$. In this method formaldehyde vapors are collected in an aqueous solution of sodium bisulphite and analyzed volumetrically. The detection limit is about $0.2 \mathrm{~cm}^{3} / \mathrm{m}^{3}$ of formaldehyde for sample volumes of 1001 .

Phenol was absorbed in a sodium hydroxide solution and analyzed spectrophotometrically as a coupling product with 4-amino-antipyrine (3). Sampling time was $1 \mathrm{~h}$; and the detection limit, $0.1 \mathrm{~cm}^{3} / \mathrm{m}^{3}$ of phenol for sample volumes of 1001 .

Phosphoric acid samples were taken in water and analyzed spectrophotometrically by the molybdenic blue method (11). The sampling time was $4 \mathrm{~h}$, and the detection limit was about $0.1 \mathrm{mg} / \mathrm{m}^{3}$ of phosphoric acid for sample volumes of 1,000 l.

\section{RESULTS}

The distribution of the furfuryl alcohol concentrations measured in the coremaking areas is presented in fig. 1 . The arithmetic mean concentration was $4.3 \mathrm{~cm}^{3} / \mathrm{m}^{3}$. Twenty-two per cent of the furfuryl alcohol measurements exceeded the threshold limit value (TLV) of $5 \mathrm{~cm}^{3} / \mathrm{m}^{3}$. The highest furfuryl alcohol concentrations (10-40 $\mathrm{cm}^{3} / \mathrm{m}^{3}$ ) were measured when large core boxes were being filled and packed manually.

Fig. 2 shows the distribution of the formaldehyde concentrations in the air during the handling of furan sand. The mean concentration was $2.7 \mathrm{~cm}^{3} / \mathrm{m}^{3}$. Thirtyeight per cent of the measurements exceeded the formaldehyde TLV $\left(2 \mathrm{~cm}^{3} / \mathrm{m}^{3}\right)$. The highest formaldehyde concentrations $\left(5-16 \mathrm{~cm}^{3} / \mathrm{m}^{3}\right)$ appeared when large core boxes were being filled.

The concentrations of phenol and phosphoric acid that were measured during the coremaking process were definitely lower than their respective TLVs. The highest phenol concentration measured was $0.35 \mathrm{~cm}^{3} / \mathrm{m}^{3}$; the $T L V$ is $5 \mathrm{~cm}^{3} / \mathrm{m}^{3}$. The phosphoric acid concentrations were less than $0.1 \mathrm{mg} / \mathrm{m}^{3}$; the TLV is $1 \mathrm{mg} / \mathrm{m}^{3}$.

\section{DISCUSSION}

As the use of furan resins containing 
$\%$ OF SAMPLES
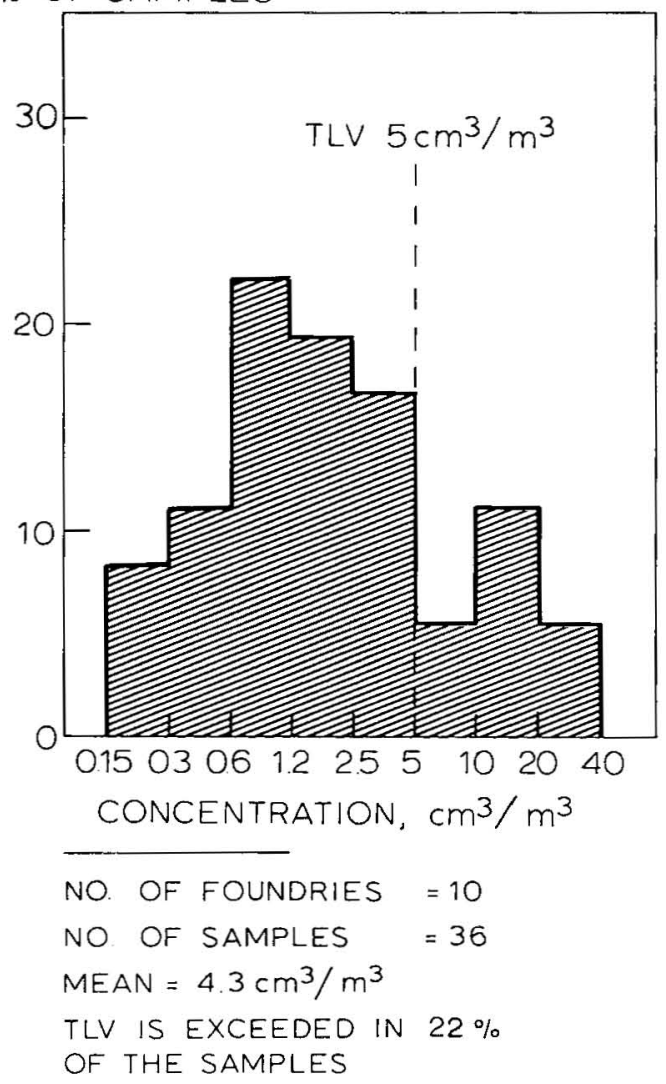

Fig. 1. Distribution of furfuryl alcohol concentrations in the coremaking areas of 10 iron and steel foundries.

furfuryl alcohol has increased, the toxicity and potiential health hazards of furfuryl alcohol have become important. The essential toxic effect of furfuryl alcohol is that of a central nervous depressant. Although small doses stimulate respiration in man and animals, large doses depress it (4). The acute effect of furfuryl alcohol vapor is irritation of the eyes and respiratory tract. Only irritations of the skin and mucous membranes have been reported as a result of industrially used furfuryl alcohol, and no systemic effects or impairment of health have been recorded (12). The TLV of $5 \mathrm{~cm}^{3} / \mathrm{m}^{3}$ for furfuryl alcohol is believed to be sufficiently low to prevent systemic and ocular effects in unconditioned workers (2).

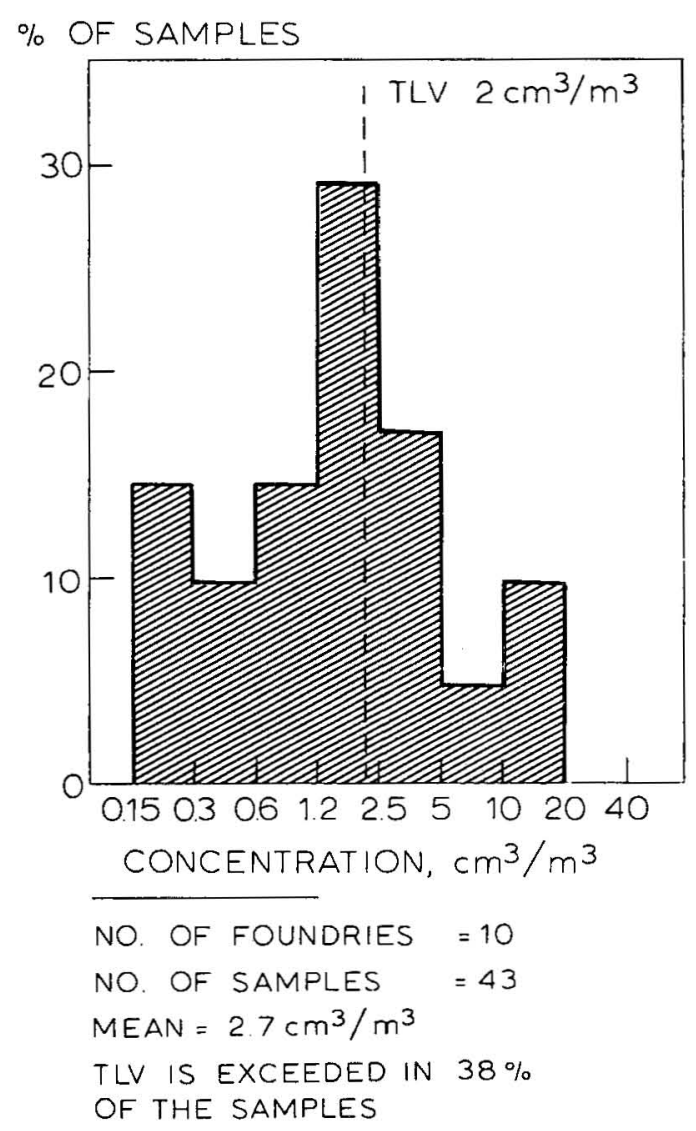

Fig. 2. Distribution of formaldehyde concentrations in the coremaking areas of 10 iron and steel foundries.

The other volatile component in furan resins, formaldehyde, causes acute irritation of the eyes and respiratory tract already at low atmospheric concentrations. Because of the solubility of formaldehyde in water, the irritant effect is limited to the initial section of the respiratory tract. A concentration of $2-3 \mathrm{ppm}$ causes a slight formication of the eyes, nose, and pharynx, at 4-5 ppm the discomfort rapidly increases, and $10 \mathrm{ppm}$ is tolerated with difficulty even briefly. Between 10 and $20 \mathrm{ppm}$, breathing is extremely difficult, the eyes, nose, and trachea burn, and intense lacrimation and severe coughing occur. The TLV of $2 \mathrm{ppm}$ for formaldehyde provides a very small safety margin against its irritant effects $(2,6,9)$. 
The present study of some Finnish foundries indicates that during the use of furan sand binders furfuryl alcohol and formaldehyde can appear in the workroom air in concentrations often exceeding the TLVs. Even though the irritative effect of these gases is primarily temporary, the question should be considered of whether exposure to these gases, together with exposure to foundry dusts and smoking, can increase the risk of chronic bronchitis (10).

\section{REFERENCES}

1. AMERICAN CONFERENCE OF GOVERNMENTAL INDUSTRIAL HYGIENISTS. Manual of analytical methods: Determination of formaldehyde in air. Cincinnati, Ohio 1958.

2. AMERICAN CONFERENCE OF GOVERNMENTAL INDUSTRIAL HYGIENISTS. Documentation of the threshold limit values for substances in workroom air (3rd ed.). Cincinnati, Ohio 1974.

3. AMERICAN PUBLIC HEALTH ASSOCIATION, INTERSOCIETY COMIMITTEE. Methods of air sampling and analysis, Washington, D.C. 1972 , pp. 220-223.

4. BROWNING, E. Toxicity and metabolism of industrial solvents. Elsevier Publishing Co., Amsterdam 1965, pp. 382-384.

5. CUTTER, J. A. and FINLAY, R. Practical experiences with airsetting resins. $B r$. foundryman 58 (1965) 397-404.

6. DEUTSCHE FORSCHUNGSGEMEINSCHAFT. Gesundheitsschädliche Arbeits- stoffe. Toxikologisch-arbeitsmedizinische Begründung von MAK-Werten. 4. Lieferung 1974. Verlag Chemie, Weinheim 1975.

7. EBSTEIN, D. The setting of no bake foundry binders based on furfuryl alconol. 33rd international foundry congress, New Delhi 1966. 13 p.

8. GOLDMAN, F. $\mathrm{H}$. and YAGODA, $\mathrm{H}$. Collection and estimation of traces of formaldehyde in air. Ind. eng. chem. 15 (1943) $377-378$.

9. INTERNATIONAL LABOR OFFICE. Encyclopedia of occupational health and safety (vol, 1). Geneva 1971, pp. 575-576.

10. KÄRÄVÄ, R., HERNBERG, S., KOSKELA, R.-S. and LUOMA, K. Prevalence of pneumoconiosis and chronic bronchitis in foundry workers. Scand. $j$. work environ. $\&$ health 2 (1976): suppl. 1, 64-72.

11. KOCH, O. G. and KOCH-DEDIC, G. A. Handbuch der Spurenanalyse. Springer Verlag, Berlin 1964, pp. 719-736.

12. MASTROMATTEO, E. Recent occupational health experiences in Ontario. $J$. occup. med. 7 (1965) 502-511.

13. MIDDLETON, J. M. Organic bonds in the steel foundry. $\mathrm{Br}$. foundryman 58 (1965): 1 , $13-24$.

14. PFÄFFLI, P. Determination of small concentrations of furfuryl alcohol in air samples. Work-environ.-health 8 (1971) 33 -38 .

15. SCHMIDT, C. H. Neuere Entwicklungen in der Furan-Chemie. Angew. Chem. 67 (1955): $12,317-326$.

16. VIRTAMO, M., PFÄFFLI, P. and SILTANEN, E. Työhygieeninen tutkimus furaanihartsin käytöstä rautavalimoissa [The potential health hazards in the use of furan resins in iron foundries] (Työterveyslaitoksen tutkimuksia no. 63). Institute of Occupational Health, Helsinki 1970. 14 p. 